\title{
FAKTOR RISIKO PASIEN NEFROPATI DIABETIK YANG DIRAWAT DI BAGIAN PENYAKIT DALAM RSUP DR. M. DJAMIL PADANG
}

Harie Satria ES ${ }^{1}$, Eva Decroli ${ }^{2}$, Afriwardi $^{3}$

\begin{abstract}
Abstrak
Diabetes melitus yang tidak terkontrol akan menyebabkan terjadinya berbagai komplikasi kronik, baik mikrovaskuler maupun makrovaskuler. Penyakit akibat komplikasi mikrovaskular yang dapat terjadi pada pasien diabetes yaitu retinopati dan nefropati diabetik. Nefropati Diabetik adalah komplikasi diabetes melitus pada ginjal yang dapat berakhir sebagai gagal ginjal. Penyakit ginjal (nefropati) merupakan penyebab utama kematian dan kecacatan pada diabetes melitus. Tujuan penelitian ini adalah melihat gambaran faktor risisko yaitu tekanan darah, glukosa darah dan kadar lipid pada penderita diabetes melitus tipe II di RSUP Dr. M. Djamil Padang tahun 2013. Metode yang digunakan adalah deskriptif retrospektif dengan desain cross sectional terhadap 37 sampel pasien diabetes melitus tipe II yang dilaksanakan pada bulan September sampai Oktober 2015 di bagian rekam medis RSUP Dr. M. Djamil Padang. Subjek penelitian ini adalah sampel penelitian yang memenuhi kriteria inklusi dan eksklusi dalam penelitian dan kemudian disajikan dalam tabel distribusi dan frekuensi. Hasil penelitian menunjukkan $70,3 \%$ pasien nefropati diabetik mengalami hipertensi. Gambaran glukosa darah pasien nefropati diabetik didapatkan bahwa sebesar 70,1\% pasien nefropati diabetik memiliki glukosa darah sewaktu yang cukup tinggi ( $>200 \mathrm{mg} / \mathrm{dl}$ ). Gambaran kadar lipid darah pasien nefropati diabetik didapatkan sebesar $94,6 \%$ pasien nefropati diabetik mengalami dislipidemia.
\end{abstract}

Kata kunci: nefropati diabetik, tekanan darah, kadar glukosa, kadar lipid

\begin{abstract}
The most microvasculer complication are retinopathy and nefropatic diabeticum. Nefropatic diabeticum is a complication of diabetes mellitus that can expand to chronic kidney disease. It can cause of death and disability of diabetes mellitus. The objective of this study was to know descriptive of risk factor, such as blood pleasure, glucosa, and lipid in tipe II diabetes mellitus patient in RSUP Dr. M. Djamil Padang in periode 2013. Method of research was a retrospective descriptive design for 36 diabetes mellitus tipe II patients conducted in Sepetember until October 2015 in medical record RSUP Dr. M. Djamil Padang. The subjects of research that fulfilled the inclusion and eksclusion criteria and be descriptived with distribusion and frekuensi table. The results of the research shows $70.3 \%$ nefropatic diabeticum patients get hypertensi. There were $70.1 \%$ nefropatic diabeticum patients have blood glucose levels enough high ( >200 mg/dl) and $94.6 \%$ nefropatic diabeticum patients have blood lipid with dislipidemia.
\end{abstract}

Keywords: nefropatic diabeticum, blood plesure, blood glucose, blood lipid

Affiliasi penulis: 1. Prodi Kedokteran Fakultas Kedokteran Universitas Andalas Paadang (FK Unand), 2. Bagian Penyakit Dalam FK Unand/RSUP Dr. M. Djamil Padang, 3. Bagian Fisiologi FK UNAND

Korespondensi: Harie Satria ES

Email: satria.harie@gmail.com, Telp: 081268391071

\section{PENDAHULUAN}

Diabetes melitus (DM) adalah suatu kelompok penyakit metabolik dengan karakteristik hiperglikemi yang terjadi karena kelainan sekresi insulin, kelainan kerja insulin atau keduanya. Gambaran patologik DM sebagian besar dapat dihubungkan dengan salah satu efek utama akibat kurangnya insulin yaitu penurunan 
pemakaian glukosa oleh sel-sel tubuh dan peningkatan metabolisme lemak, serta berkurangnya protein dalam jaringan tubuh. ${ }^{1,2}$

Prevalensi diabetes mellitus di dunia meningkat sangat pesat dalam 2 dekade terakhir. Meskipun prevalensi DM tipe I dan tipe II sama-sama meningkat, namun DM tipe II kelihatannya akan lebih cepat peningkatannya di masa depan karena semakin tingginya angka obesitas dan semakin kurangnya aktivitas fisik manusia. Pada tahun 2000, prevalensi DM diperkirakan 0,19\% pada orang umur $<20$ th dan $8,6 \%$ pada orang umur $>20$ th. Pada lansia $>65$ th prevalensi DM adalah 20,1\%. Prevalensi pada pria dan wanita sama, kecuali pada usia $>60$ th lebih tinggi pria dibanding wanita. ${ }^{3}$

Diabetes melitus yang tidak terkontrol akan menyebabkan terjadinya berbagai komplikasi kronik, baik mikrovaskuler maupun makrovaskuler. Manifestasi komplikasi makrovaskuler dapat berupa penyakit jantung koroner, trombosis serebral, dan gangrene. Penyakit akibat komplikasi mikrovaskular yang dapat terjadi pada pasien diabetes yaitu retinopati dan nefropati diabetik. ${ }^{4}$

Nefropati Diabetik adalah komplikasi diabetes melitus pada ginjal yang dapat berakhir sebagai gagal ginjal. Penyakit ginjal (nefropati) merupakan penyebab utama kematian dan kecacatan pada DM. Sekitar 50\% gagal ginjal tahap akhir di Amerika Serikat disebabkan nefropati diabetik. Hampir $60 \%$ penderita hipertensi dan diabetes di Asia menderita Nefropati diabetik. ${ }^{5,6}$

Pada tahun 1981 Nefropati diabetika merupakan penyebab kematian urutan ke-6 di negara barat dan saat ini $25 \%$ penderita gagal ginjal yang menjalani dialisis disebabkan oleh karena diabetes melitus terutama DM tipe II oleh karena DM tipe ini lebih sering dijumpai. ${ }^{7}$

Perkembangan penyakit DM menjadi penyakit ginjal stadium akhir diduga dipengaruhi oleh berbagai faktor yang terlibat, antara lain: faktor genetik, diet, dan kondisi medis yang lain seperti hipertensi serta kadar gula darah yang tinggi dan tidak terkontrol. ${ }^{4}$

Faktor risiko yang dihubungkan dengan terjadinya gagal ginjal tahap akhir nefropati diabetik menurut penelitian antara lain peningkatan tekanan darah, kontrol gula darah yang buruk, dislipidemia, usia tua, resistensi insulin, merokok, jenis kelamin, ras dan asupan tinggi protein. ${ }^{8}$

Ada berbagai faktor risiko terkait terjadinya komplikasi kronik diabetes mellitus nefropati diabetik. Terdapat 3 usaha umum dalam strategi pengelolaan komplikasi DM tersebut yaitu, pengendalian konsentrasi glukosa, tekanan darah, dan pengendalian lipid. $^{4}$

Usaha pengelolaan dari faktor risiko nefropati diabetik yang baik sudah jelas dapat menunda timbulnya gagal ginjal terminal, tetapi sampai saat ini belum didapatkan cara yang baik untuk menghentikan perkembangan ke arah ginjal terminal. ${ }^{4}$

Berdasarkan hal tersebut di atas maka dalam penelitian ini akan dikaji faktor risiko yang menimbulkan nefropati diabetik pada penderita DM tipe II yang dirawat di Bagian IImu Penyakit Dalam RSUP Dr. M. Djamil Padang, sehingga diharapkan dapat menunda perkembangan ke arah gagal ginjal terminal.

\section{METODE}

Penelitian ini merupakan studi deskriptif retrospektif. Populasi adalah seluruh data rekam medis pasien DM tipe II dengan komplikasi nefropati diabetik yang dirawat di Bagian Penyakit Dalam RSUP. Dr. M. Djamil Padang tahun 2013. Sampel penelitian diambil dari data sekunder pasien DM tipe II dengan komplikasi nefropati diabetik di RSUP Dr. M. Djamil Padang dengan metode total sampling. Adapun kriteria inklusi dari penelitian ini adalah data rekam medis lengkap meliputi nomor registrasi pasien, umur, jenis kelamin, tekanan darah pasien, kadar glukosa darah pasien, kadar kolesterol total, HDL, LDL dan trigliserida pasien. Kriteria eksklusi adalah pasien yang menderita nefropati diabetik disertai dengan penyebab penyebab penyakit ginjal kronik lain seperti infeksi dan payah jantung. Penelitian dilaksanakan pada Bulan September - Oktober 2015 di bagian rekam medis RSUP. Dr. M. Djamil Padang. 
HASIL

Tabel 1. Distribusi sampel penelitian berdasarkan usia

\begin{tabular}{llll}
\hline No & Karakteristik & $\mathbf{n = 3 7}$ & $\%$ \\
\hline $\mathbf{1}$ & Usia & 12 & 32,4 \\
& 40-49 tahun & 17 & 45,9 \\
& 50-59 tahun & 8 & 21,6 \\
& $>60$ tahun & & \\
\multirow{2}{*}{} & Jenis Kelamin & 17 & 45,9 \\
& Laki-laki & 20 & 54,1 \\
& Perempuan & &
\end{tabular}

Pada Tabel 1 terlihat bahwa penderita Penyakit Gagal Ginjal (PGK) terbanyak pada kelompok usia 5059 tahun $(45,9 \%)$ dan jenis kelamin terbanyak adalah perempuan yaitu $54,1 \%$.

Tabel 2. Gambaran tekanan darah pasien nefropati diabetik

\begin{tabular}{lll}
\hline Kategori & $\mathbf{n}$ & $\%$ \\
\hline Hipotensi & 1 & 2,7 \\
Normal & 2 & 5,4 \\
Pre Hipertensi & 8 & 21,6 \\
Hipertensi Tahap I & 8 & 13,5 \\
Hipertensi Tahap II & 21 & 56,8 \\
\hline Jumlah & 37 & 100 \\
\hline
\end{tabular}

Tabel 2 menunjukkan sebagian besar pasien nefropati diabetik menderita hipertensi tahap II $(56,8 \%)$.

Tabel 3. Gambaran kadar glukosa darah pasien nefropati diabetik

\begin{tabular}{lcc}
\hline Kategori & $\mathbf{n}$ & $\%$ \\
\hline Baik (glukosa darah sewaktu <200 ng/dl) & 11 & 29,7 \\
Buruk (glukosa darah sewaktu >200 ng/dl) & 26 & 70,1 \\
\hline Jumlah & 37 & 100
\end{tabular}

Berdasarkan Tabel 3 didapatkan sampel terbanyak memiliki kadar glukosa darah buruk yaitu lebih dari $200 \mathrm{ng} / \mathrm{dl}(70,1 \%)$.

Pada Tabel 4 terlihat bahwa pasien yang mengalami dislipidemia (Kolesterol total >200 atau kolesterol LDL > 130 atau kolesterol HDL < 35 atau trigliserida >150) adalah 35 pasien (94,6\%).
Tabel 4. Gambaran kadar lipid darah pasien nefropati diabetik

\begin{tabular}{lll}
\hline Kategori & $\mathbf{n}$ & $\%$ \\
\hline Kolesterol total : $\geq 200 \mathrm{mg} / \mathrm{dl}$ & 18 & 48,6 \\
Kolesterol LDL : $\geq 130 \mathrm{mg} / \mathrm{dl}$ & 20 & 54 \\
Kolesterol HDL: $<35 \mathrm{mg} / \mathrm{dl}$ & 21 & 56,7 \\
Trigliserida $: \geq 150 \mathrm{mg} / \mathrm{dl}$ & 24 & 64,9 \\
\hline Jumlah & 37 & 100 \\
\hline
\end{tabular}

\section{PEMBAHASAN}

Penelitian telah dilakukan di RSUP Dr. M. Djamil Padang dengan jumlah sampel 37 rekam medis pasien DM tipe II dengan komplikasi nefropati diabetik yang dirawat di bangsal penyakit dalam RSUP. Dr. M. Djamil Padang pada tahun 2013. Dari penelitian memperoleh rentang usia 18-73 tahun dengan kejadian terbanyak yaitu pada usia 50-59 tahun.

Pada pasien DM Tipe II kejadian nefropati diabetes berkisar antara $12-16 \%$ pada pasien DM yang terdiagnosis pada usia $>40$ tahun. Kejadian proteinuria juga meningkat dari $7-10 \%$ pada mereka yang sudah terdiagnosis selama 5 tahun menjadi 20$35 \%$ pada yang sudah menderita DM 20- 25 tahun. Sebanyak 5-10\% pasien DM Tipe II dengan nefropati diabetes akan berkembang menjadi gagal ginjal terminal. $^{4}$

Tekanan darah pasien dengan nefropati diabetik ini didapatkan bahwa sebanyak $70,3 \%$ pasien menderita hipertensi dimana $13,5 \%$ pasien mengalami hipertensi tahap I dan $56,8 \%$ pasien mengalami hipertensi tahap II.

Hipertensi sistemik menyebabkan hiperfiltrasi dan abnormalitas hemodinamik, yang mana membantu perkembangan kerusakan glomeruli dan nefropati diabetik. Kekuatan hemodinamik intraglomerular abnormal mengubah pertumbuhan dan fungsi glomeruli, mesangial dan sel-sel epitel dengan meningkatkan tekanan fisik dan mekanis, mengakibatkan pembentukan matriks mesangial meningkat dan penebalan membran basalis yang merupakan ciri khas nefropati diabetik. ${ }^{10}$

Kontrol glukosa darah pasien DM tipe II yang mengalami komplikasi nefropati diabetik didapatkan 
bahwa kontrol glukosa darah yang buruk sebesar $70,3 \%$. Hasil penelitian diketahui bahwa sebanyak 26 pasien mempunyai kadar glukosa darah sewaktu di atas $200 \mathrm{mg} / \mathrm{dl}$. Hal ini disebabkan karena kadar glukosa yang tinggi menyebabkan produsi Advanced Glycosilation Product (AGEs) yang dapat mengubah protein struktur dan disfungsi vaskuler, lesi glomerulus, proteinuria dan bias berakhir dengan gagal ginjal. ${ }^{10}$

Pada hasil penelitian, didapatkan hasil bahwa pasien yang mengalami dislipidemia (kolesterol total >200 atau kolesterol LDL > 130 atau kolesterol HDL $<35$ atau trigliserida >150) adalah 35 pasien (94,6\%). Hal ini disebabkan karena kadar lipid yang tinggi dalam pembuluh darah akan menyebabkan atesklerosis. Aterosklerosis ini akan mengenai arteri renalis sehingga menghambat LFG dan meningkatkan resiko nefropati diabetik. ${ }^{10}$

Beberapa penelitian juga membuktikan adanya penurunan kadar albumin urin yang signifikan setelah dilakukan intervensi diet. Hasil penelitian ini konsisten dengan penelitian lain yang menyatakan bahwa terjadi perubahan kadar albuminuria setelah dilakukan koreksi glikemik pada DM tipe II. Perubahan ini mungkin disebabkan karena perubahan hemodinamik akibat penurunan glikemia dan juga mungkin disebabkan karena penurunan intake protein. Hubungan antara kadar lipid plasma, albuminuria, dan gangguan fungsi ginjal juga dilaporkan oleh sebuah penelitian dengan 585 sampel yang melakukan diet selama 3 tahun dan berhasil menurunkan kadar albuminuria, tetapi kadar glukosa puasa dan trigliserid bervariasi. Kadar trigliserid juga berhubungan dengan peningkatan albuminuria dan proteinuria. ${ }^{11}$

Dalam penelitian ini, ada beberapa orang pasien nefropati diabetik yang menunjukkan tekanan darah normal, glukosa darah normal dan juga kadar lipid yang normal, tetapi pada pasien ini tetap terjadi nefropati diabetik. Nefropati diabetik pada pasien ini terjadi karena faktor resiko lain seperti genetik. Resiko nefropati kemungkinan ditentukan oleh genetik, yang dikaitkan dengan tempat kromosom tertentu. Gen yang terlibat belum dapat diidentifikasi. ${ }^{12}$

Intake tinggi juga bisa menjadi penyebab terjadinya komplikasi nefropati diabetik. Diet tinggi protein akan meningkatkan resiko untuk terjadinya suatu nefropati dan gagal ginjal tahap akhir. Diet tinggi protein ini akan menyebabkan kenaikan filtrasi glomerulus, hipertensi kapiler dan akhirnya kerusakan glomerulus. $^{12}$

Hormon vasoaktif juga berperan terhadap progresivitas nefropati diabetik. Beberapa hormon vasoaktif seperti kinin, prostaglandin, atrial natriuretik peptide serta nitrit oksida memainkan peranan dalam perubahan hemodinamik ginjal dan berimplikasi pada inisiasi dan progresi nefropati diabetik. ${ }^{8}$

\section{SIMPULAN}

Gambaran glukosa darah pasien nefropati diabetik sebagian besar memiliki glukosa darah sewaktu yang cukup tinggi. Gambaran kadar lipid pasien nefropati diabetik didapatkan bahwa pasien banyak yang mengalami dislipidemia. Dislipidemia ini disimpulkan dari kolesterol HDL, kolesterol LDL, kolesterol total dan trigliserida yang terganggu.

\section{UCAPAN TERIMA KASIH}

Terimakasih yang sedalam-dalamnya kepada Direktur RSUP Dr. M. Djamil Padang dan kepala bagian rekam medis beserta staf yang telah memberikan izin untuk pengambilan data penelitian sehingga penelitian ini dapat diselesaikan.

\section{DAFTAR PUSTAKA}

1. PB Perkumpulan Endokrinologi Indonesia (PB PERKENI). Konsensus Pengelolaan dan Pencegahan Diabetes Mellitus Tipe 2 di Indonesia. Jakarta: PB PERKENI; 2006.

2. Guyton AC, Hall JE. Buku ajar fisiologi kedokteran. Edisi ke-9. Setiawan I, Tengadi KA, Santosa A (penerjemah). Textbook of Medical Physiology. 8th Edition. Jakarta: EGC; 2007.

3. Ritz E, Keller C, Kristian H. Bergis. Nephropathy of type II diabetes mellitus. Nephrol Dial Transplant. 2000;11(9):38-44.

4. Waspadji S. Diabetes mellitus: mekanisme dasar dan pengelolaannya yang rasional. Dalam: Soegondo S, et al: Penatalaksanaan diabetes mellitus terpadu. Jakarta: Fakultas Kedokteran Universitas Indonesia; 2005 
5. Mogensen CE. Microalbuminuria, blood pressure and diabetic renal disease: origin and development of ideas. Dalam: Mogensen CE, editor (penyunting). The kidney and hypertension in diabetes mellitus. 5th ed. Boston Kluwer; 2000.

6. American Diabetes Association. Hypertension management in adults with diabetes (position statement). Diabetes Care. 2004;1:65-7.

7. Daniel W. Foster. Diabetes mellitus. Dalam: Harrison Prinsip-Prinsip IImu Penyakit Dalam (terjemahan). Edisi ke-13, Jakarta: EGC; 1994.hlm. 2212-13.

8. World Health Organization (WHO). Prevention of diabetes. Dalam: Arisman (penterjemah). Pencegahan diabetes mellitus. Jakarta: Hipocrates;1995.
9. Soewanto. Nefropati diabetik: pathogenesis, klasifikasi, dan terapi. Dalam: Symposium nasional diabetes dan lipid. Surabaya: PB PERKENI; 1994.hlm.78-81.

10. Jennifer BM, Paskin P. Nephropathy and hypertension in diabetes. Dalam: The medical clinics of North America, prevention and treatment of diabetes and its complications. USA;1998.hlm.879-99.

11. Bilous R. Review article microvascular disease: what does the UKPDS tell us about diabetic nephropathy. Diabetes Med Journal. 2008;2:25-9.

12. Ritz E, Orth SR. Nephropathy in patients with type 2 diabetes mellitus. Massachusetts Medical Society.1999;341:1127-32. 